\title{
Oct-4: a germline-specific transcription factor mapping to the mouse $t$-complex
}

\author{
Hans R.Schöler, Gregory R.Dressler ${ }^{1}$, Rudi \\ Balling, Heidi Rohdewohld and Peter Gruss \\ Max-Planck-Institute for Biophysical Chemistry, Department of \\ Molecular Cell Biology, 3400 Göttingen, FRG \\ 'Present address: NIH/NICHD Building 6, Bethesda, MD 20892, USA \\ Communicated by P.Gruss
}

Oct -4 is a maternally expressed octamer-binding protein encoded by the murine 0 ct-4 gene. It is present in unfertilized oocytes, but also in the inner cell mass and in primordial germ cells. Here we show that the ectopic expression of Oct- 4 in HeLa cells is sufficient for transcriptional activation from the octamer motif, indicating that Oct -4 is a transcription factor. Therefore, Oct- 4 is the first transcription factor described that is specific for the early stages of mouse development. The spatial and temporal expression patterns were further determined using in situ hybidization. With this technique Oct -4 expression is detected in the oocyte, in the blastocyst and before gastrulation in the embryonic ectoderm. After day 80 oct -4 expression decreases and is restricted to primordial germ cells from about day 8.5 onwards. Therefore Oct-4 is a transcription factor that is specifically expressed in cells participating in the generation of the germline lineage. Linkage analysis using $B \times D$ recombinant inbred mouse strains demonstrates that Oct-4 maps to chromosome 17 in or near the major histocompatibility complex. Several mouse mutants in the distal region of the mouse $t$-complex affecting blastocyst and embryonic ectoderm formation also map to this region.

Key words: embryogenesis/germline/maternal/octamer/ $t$-complex

\section{Introduction}

Based on studies with Drosophila, current models of development predict a hierarchy of regulatory genes guiding the transformation of genetic information into embryonic structure (for a review see Ingham, 1988). A number of mouse genes identified by sequence similarity to Drosophila genes may be involved in pattern formation (Holland and Hogan, 1988; Kessel and Gruss, 1990). However, these genes are expressed at later stages of mouse development. Identification of regulatory proteins specific for early stages of embryogenesis might help to unravel the predicted developmental gene hierarchy of the mouse.

The octamer motif is a well-characterized cis-acting element found in many promoters and enhancers (for a review see Hatzopoulos et al., 1988). Octamer-binding proteins from $\mathrm{B}$ or $\mathrm{HeLa}$ cells regulate transcription via the octamer sequence motif (Dreyfus et al., 1987; Scheidereit et al., 1987; Wirth et al., 1987; LeBowitz et al., 1988;
Müller-Immerglück et al., 1988; Tanaka et al., 1988; Thali et al., 1988). In F9 cells the octamer mediates both transcriptional activation (Schöler et al., 1989b) and repression (Lenardo et al., 1989). In these cells, three octamer-binding proteins are found in addition to the ubiquitously expressed Oct-1 protein (Schöler et al., 1989a). Oct-4 and Oct-5 are encoded by the Oct-4 gene (Schöler et al., 1990) whereas the gene encoding Oct- 6 remains to be isolated. Oct -4 and Oct- 5 are also found in primordial germ cells, unfertilized oocytes and in the inner cell mass (ICM) of blastocysts. Therefore, Oct- 4 and Oct-5 could control events in early mouse embryogenesis.

We show that expression of $O c t-4$ cDNA was sufficient to activate transcription from the octamer motif, indicating that Oct -4 is a transcription factor. Also, the expression pattern of the Oct-4 gene during embryogenesis was determined by in situ hybridization and the electrophoretic mobility shift assay (EMSA). In preimplantation embryos, Oct-4 expression was found in the blastocyst and before gastrulation in the embryonic (primitive) ectoderm. Between day 8 and 8.5 p.c., expression decreased dramatically and was restricted at day 8.5 to the primordial germ cells which were identified at the base of the allantois by histological alkaline phosphatase staining (Stinnakre et al., 1981). The primordial germ cells migrate from the base of the allantois to the genital ridges (Chiquoine, 1954; Clark and Eddy, 1975) where they were easily detected both by their alkaline phosphatase activity and their Oct-4 expression. Linkage analysis using $\mathrm{B} \times \mathrm{D}$ recombinant inbred mouse strains demonstrated that $O c t-4$ maps in or near the major histocompatibility complex (MHC). A cluster of $t$-lethal genes are also associated with the MHC (Artzt, 1984), some of which have profound effects on early mouse development. Correlations between the Oct-4 expression pattern and the phenotype of certain $t$-haplotypes lethals are discussed.

\section{Results}

\section{Transcriptional activation by cloned Oct-4}

Depending on its context relative to other motifs, the octamer sequence confers transcriptional activation (Schöler et al., 1989b) or repression (Lenardo et al., 1989) in F9 cells. In addition to Oct-1, three octamer binding proteins are also present in F9 cells that may modulate the activation or repression response of the octamer motif (Schöler et al., 1989a). These include Oct -4 and Oct-5, which are differential translation products of the same gene (Figure 1a; Schöler et al., 1990).

The $O c t-4$ cDNA was inserted in both orientations into the eukaryotic CMV expression vector (Severne et al., 1988) used previously to investigate transcriptional activation by Oct-2A (Müller-Immerglück et al., 1988; Schreiber et al., 1988; Thali et al. , 1988). In this vector, transcription is under the control of the human CMV enhancer/promoter combined with a herpes simplex virus thymidine kinase (tk) leader 


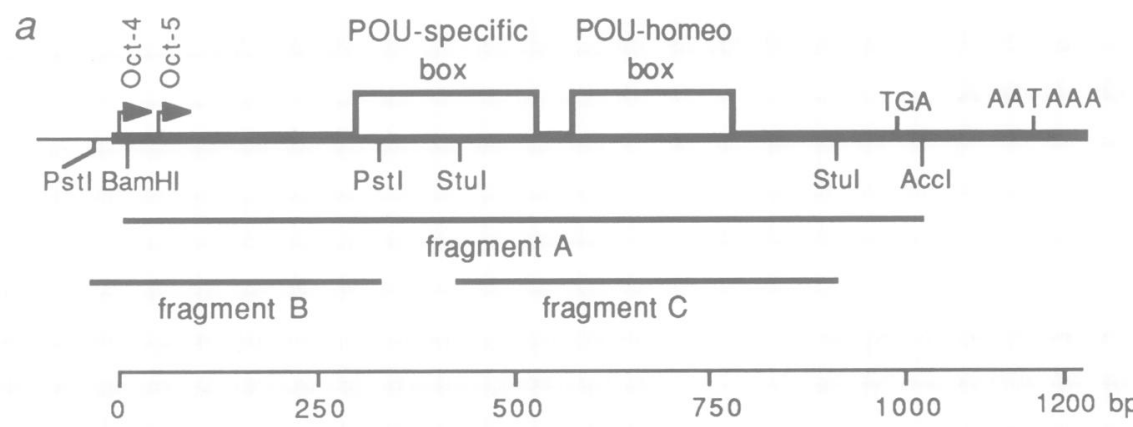

$b$

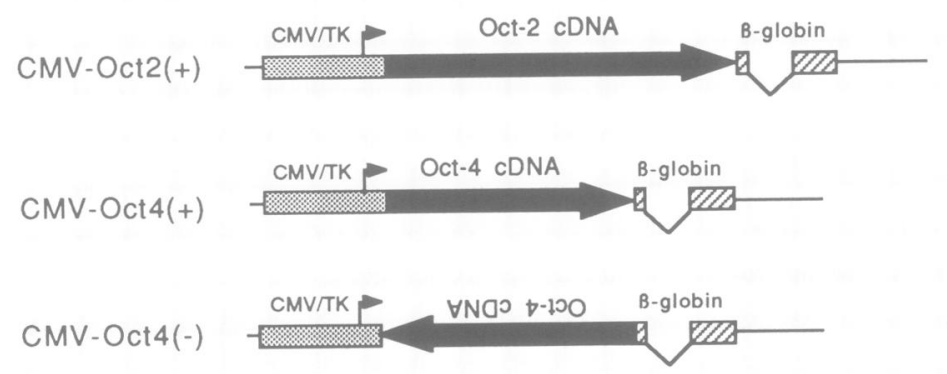

C
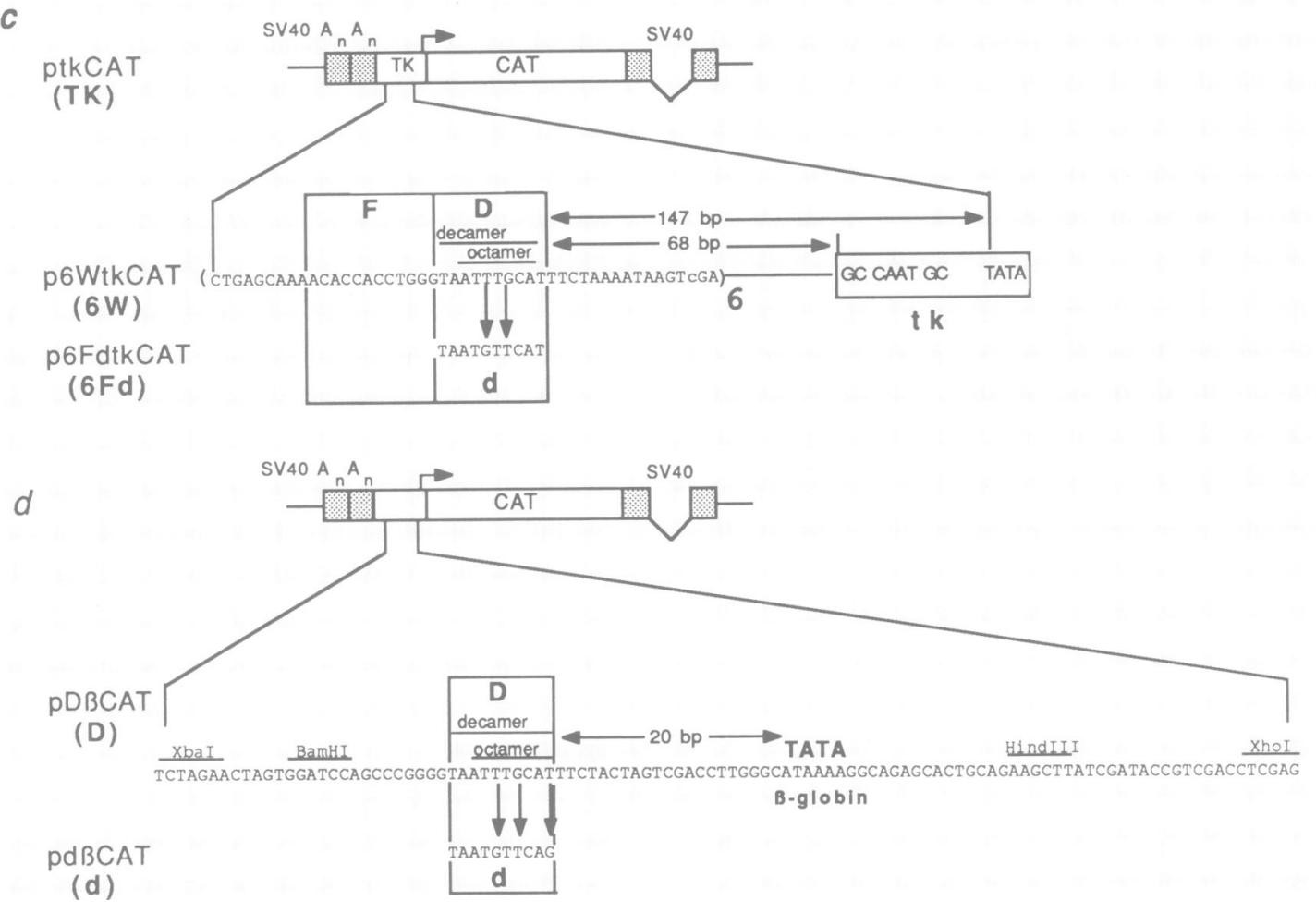

Fig. 1. Vectors and probes used for the analysis of the Oct-4 gene. (a) Structure of the Oct-4 cDNA. The arrows indicate the start sites for Oct-4 and Oct-5, TGA the stop codon and AATAAA the polyadenylation hexamer. The thin line upstream of the Oct-4 start represents polylinker sequences. Only restriction sites used for cloning and for generating probes are included. (b) shows the expression vectors and (c, d) the reporter plasmids used in the trans-activation experiments. The sequence of the p6Wtk promoter region is outlined in Materials and methods (Figure 9).

(Figure 1b). The coding sequence of $O c t-2 A$ in this vector was replaced by that of $O c t-4$, utilizing the same tk leader sequence and the same tk ATG. Due to the cloning procedure, the ATG of $\mathrm{Oct}-4$ was deleted, resulting in a slightly different Oct-4 translation product in vitro and also in vivo when ectopically expressed in HeLa cells. The size of Oct-5 remained unaffected (data not shown).
Two sets of target vectors were used in the trans-activation experiments. First a set of target vectors was tested that shows that the octamer motif is active in stem cells which contain Oct-4 and Oct-5 (Schöler et al., 1989b). These vectors (Figure 1c) either contain six tandem repeats of a mouse immunoglobulin heavy chain gene enhancer $(\mathrm{IgH})$ fragment, or mutated counterparts thereof, in front of a 
minimal TK promoter. The distance between the TATA box and the nearest octamer motif in these vectors is $147 \mathrm{bp}$. The IgH fragments (1W) harbor the native (D) or mutated (d) octamer motif and the $\mu \mathrm{E} 4$ site (F) (Church et al., 1985; Ephrussi et al., 1985). In F9 stem cells the 6W enhancer is at least 1000 -fold more active than the mutated counterpart (Schöler et al., 1989b).

The cDNA-containing expression vectors and the CAT reporter plasmids were co-transfected in different combinations into HeLa cells. Expression of Oct- 4 and Oct-2A was confirmed by EMSA (data not shown). Reporter gene expression was measured by the CAT assay and compared with expression of a reference gene $(\beta$-actin-lac $Z)$ (Figure $2)$. Surprisingly, trans-activation was not observed with the Oct-4 (lanes 6 and 7) or Oct-2A (lanes 1 and 2) expression vectors. Although the CAT activities of p6WtkCAT and pFdtkCAT are higher than ptkCAT (lanes 5 and 10), no difference was observed between $6 \mathrm{~W}$ and $6 \mathrm{Fd}$, indicating that no trans-activation was occurring via the octamer motif. Activation above ptkCAT control is likely to be due to the $\mu \mathrm{E} 4$ motif, because similar results were obtained after transfection without trans-activator (Schöler et al., 1989b).

A second set of target vectors (Figure 1d), in which a single IgH octamer $(\mathrm{pD} \beta C A T)$ or its mutated counterpart $(\operatorname{pd} \beta C A T)$ is close to the rabbit $\beta$-globin TATA box, was tested in trans-activation assays. This particular arrangement of TATA box and octamer motif is trans-activated by Oct-2A (Müller-Immerglück et al., 1988, 1990). Reporter gene expression was measured by the CAT assay and compared with lacZ expression. In the absence of a functional transactivator, reporter gene expression was not detectable (Figure 2 , lanes 11 and 12), whereas co-transfection of functional Oct -4 or Oct-2A significantly induced reporter gene expression via the octamer motif (lanes 3,4 and 8,9). Transactivation by Oct- 4 was about twice as high as by Oct-2A (lanes 3 and 8), although about ten times more radiolabeled 1W was shifted by Oct-2A than by Oct- 4 in the EMSA (not shown).

\section{Expression of the Oct-4 gene in oocytes and the preimplantation embryo}

Oct- 4 is detectable in extracts of unfertilized oocytes (Schöler et al., 1989a), blastocysts (Figure 3) and in two cell lines derived from the mouse ICM, D3 (Schöler et al., 1989a) and $t^{l u b l}$ (not shown) (Winking and Guenet, 1978). An Oct-4-like protein is also found in the human embryonal carcinoma line NT2 (not shown), a subclone of the Tera- 2 cell line (Fogh, 1978). With the standard procedure (see Materials and methods) this complex has a slightly lower mobility than the F9 Oct-4 complex (not shown). The presence of Oct- 4 correlates with transcriptional activity via the octamer motif in cells derived from the ICM (Schöler et al., 1989b). In blastocysts, lacZ expression mediated by the octamer is only in the ICM (Schöler et al., 1989b).

The distribution of Oct-4 transcripts in the ovary and during early mouse embryogenesis was determined by in situ hybridization using ${ }^{35} \mathrm{~S}$-labelled probes. Sense and antisense RNA probes were transcribed from linearized plasmids containing a 462 bp Oct-4 cDNA insert (Figure 1a; fragment $\mathrm{C}$ ).

To investigate $\mathrm{Oct}-4$ transcription at the preimplantation stage, blastocysts were recovered from the oviduct and uterus, transferred into oviducts and treated as described by

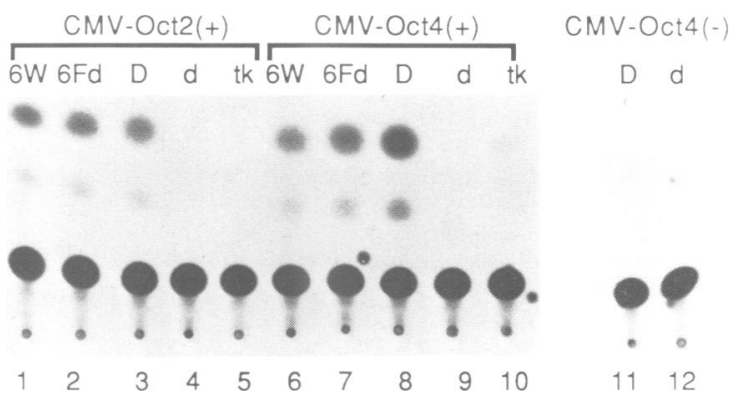

Fig. 2. Promoter activation by cloned Oct-4. The expression vectors [CMV-Oct2(+); CMV-Oct4(+); CMV-Oct4(-)] and reporter plasmids

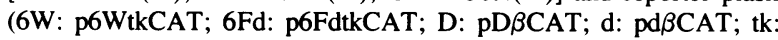
ptkCAT) were cotransfected with $\beta$-actin - lac $Z$ into HeLa cells as indicated. The expression vectors and reporter plasmids are outlined in Figure 1 .

Lyons et al. (1989) and Graham et al. (1989). With this procedure, high levels of $\mathrm{Oct}-4$ transcripts were detectable in the blastocyst (Figure $3 b-d$ ). In the early (b) and in the expanding blastocyst (c) Oct-4 is expressed uniformly. Thereafter, expression decreases significantly in the trophoblast, and increases in the ICM (d). No signal is detectable in cells of the oviduct (Figure $3 \mathrm{e}$ ) or with sense RNA (not shown).

Oct-4 expression is also found in oocytes, where it is readily detectable in a bright-field image of the ovary (Figure 3f). The signal intensity in the blastocyst is much higher than in the oocyte, probably due to higher expression of Oct-4 in the blastocyst (Figure $3 \mathrm{~g}$ ).

\section{Expression of the Oct-4 gene in the postimplantation embryo}

At the egg cylinder stage, Oct 4 transcripts can be easily detected in the embryonic ectoderm. Figure $4 a$, b shows a mid-frontal section through a 7 day embryo where the ectodermal and endodermal germ layers can be easily discerned. High levels of $\mathrm{Oct}-4$ transcripts are visible in the ectoderm, but no transcripts above background are detectable in endoderm, trophoblast, allantois and other extraembryonic tissues. At this stage, mesoderm is formed by ingression through the primitive streak. In a rear-frontal section of a 7 day embryo (Figure 4c) and a cross section through a 7.5 day embryo (Figure $4 \mathrm{~d}$ ), it is apparent that mesoderm does not express 0 ct-4 at the high levels found in ectoderm. Ectodermal expression can already be detected by day 6 in embryonic ectoderm (data not shown).

By day 8.0 ingression through the primitive streak is almost complete and the neural tube begins to take shape. Oct-4 continues to be expressed in neural ectoderm at high levels, as shown in Figure 5a, b. (Note that the head fold is evident although no somites are discernible in this particular embryo). Approximately $12 \mathrm{~h}$ later, when somitogenesis has begun, the levels of $\mathrm{Oct}-4$ transcripts start to decrease. Figure 5c, d shows an 8.5 day embryo with a well developed headfold and foregut pocket. This is a skewed sagittal section through the neural tube which has not yet closed. This embryo has 5-6 visible somites, although only those adjacent to the neural tube cross-section are visible in this section. The level of expression as estimated from the dark field picture is clearly less than at days 7 and 8 . In addition, it appears that expression in the 


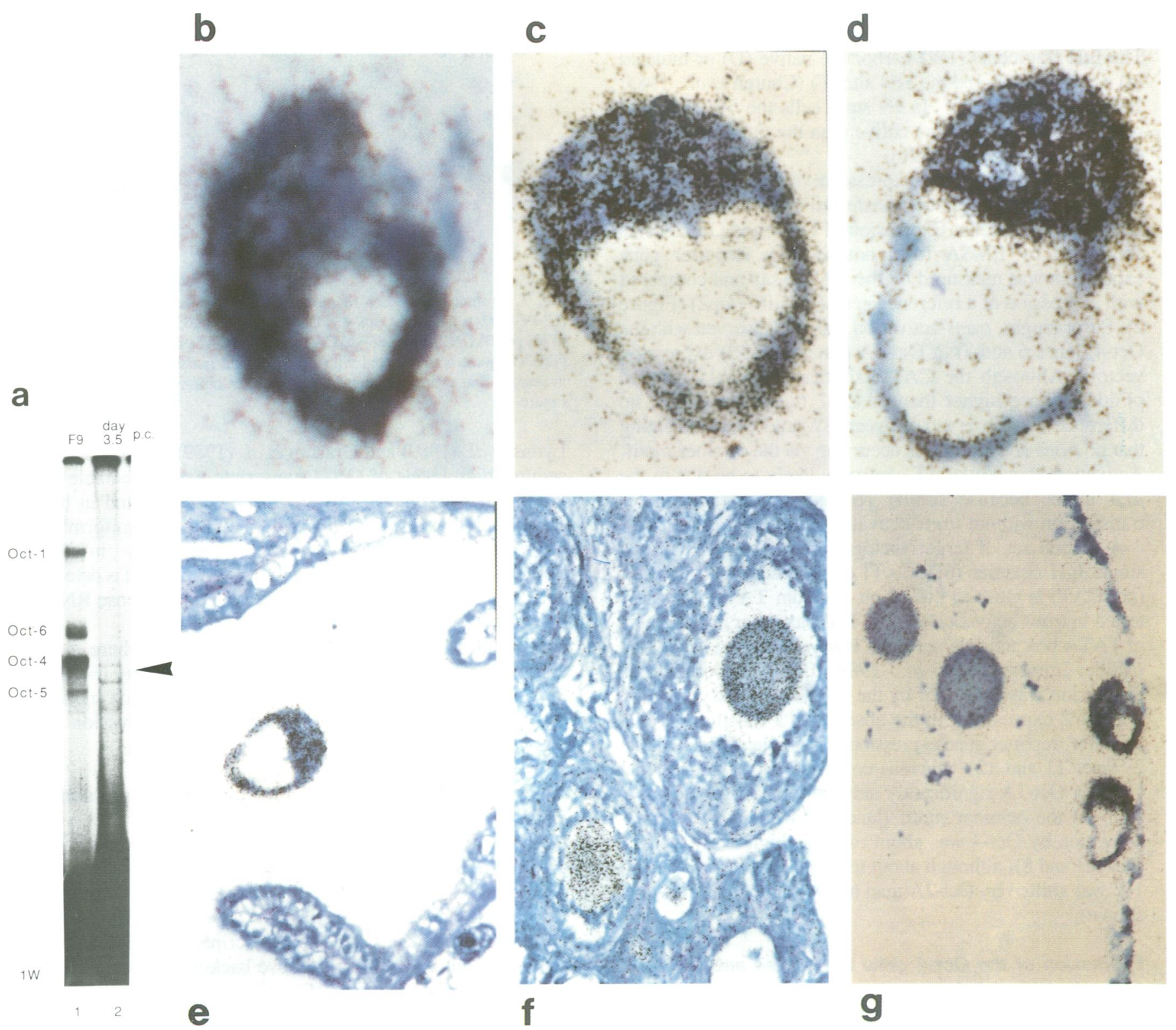

Fig. 3. Expression of Oct-4 in mouse oocytes and blastocysts. (a) Presence of Oct-4 in mouse blastocysts. Radiolabelled 1W was incubated with whole cell extracts of undifferentiated F9 cells (lane 1) and blastocysts (lane 2). The shift corresponds to an extract of ten day 3.5 blastocysts. (b to d): In situ hybridization of Oct-4 anti-sense RNA to an early (b), an expanding (c) and a late blastocyst (d), showing a restriction of $O c t-4$ expression to the ICM during blastocyst development. The late blastocyst has probably 'hatched' from the zona pellucida, as indicated by the elongated body and the flattened trophoblastic cells. $(\mathbf{e}-\mathbf{g})$ : In situ hybridization to sections of an oviduct (e, $\mathbf{g})$ and an ovary (f) showing that an Oct-4 signal is detectable only in oocytes and blastocysts. (f) shows Oct-4 expression in a small, a medium and a large follicle. At the lower left corner a type $3 \mathrm{~b}$ (or 4 ), right next to it a type 1 (or 2 ) and at the higher right corner a type $5 \mathrm{~b}$ follicle is identified according to Pedersen and Peters (1968). One oocyte is not attached to follicle cells in (f), due to shrinkage of the oocyte and the zona pellucida during fixation. This is probably also seen in (g), where follicle cells are found around the oocyte. The hybridization signal is higher in blastocysts than in oocytes as shown in (g). $\mathrm{b}-\mathrm{g}$ are bright-field images of oviduct and ovary sections.

neural folds is lower than at the posterior end of the neural tube. The primordial germ cells, located at the posterior end of the embryo where the allantois, the amniotic membrane and the three germ layers of the embryo converge (Chiquoine, 1954; Clark and Eddy, 1975), also express high levels of Oct-4. Figure 6a shows a section of a day 8.5 embryo and Figure $6 \mathrm{~b}$ an enlarged section. Both are stained for alkaline phosphatase activity, a convenient marker for primordial germ cells. A similar section of another embryo shows several clusters of cells in the expected position of the primordial germ cells expressing high levels of $O c t-4$
(Figure 6c). After day 8.5, expression continues to decrease to undetectable levels in ectoderm derived tissues, whereas the primordial germ cells continue to express $O c t-4$.

Migration of the primordial germ cells through the mesenteries to their final place in the developing gonads is complete by day 11. At this stage, germ cells can be identified in the genital ridge by alkaline phosphatase staining, and $O c t-4$ transcripts can still be easily detected (Figure $5 e, f)$. No other tissue exhibits detectable levels of Oct-4 transcripts, including all neural tissue derived from the ectodermal germ layer. Thus, $O c t-4$ is down-regulated from 


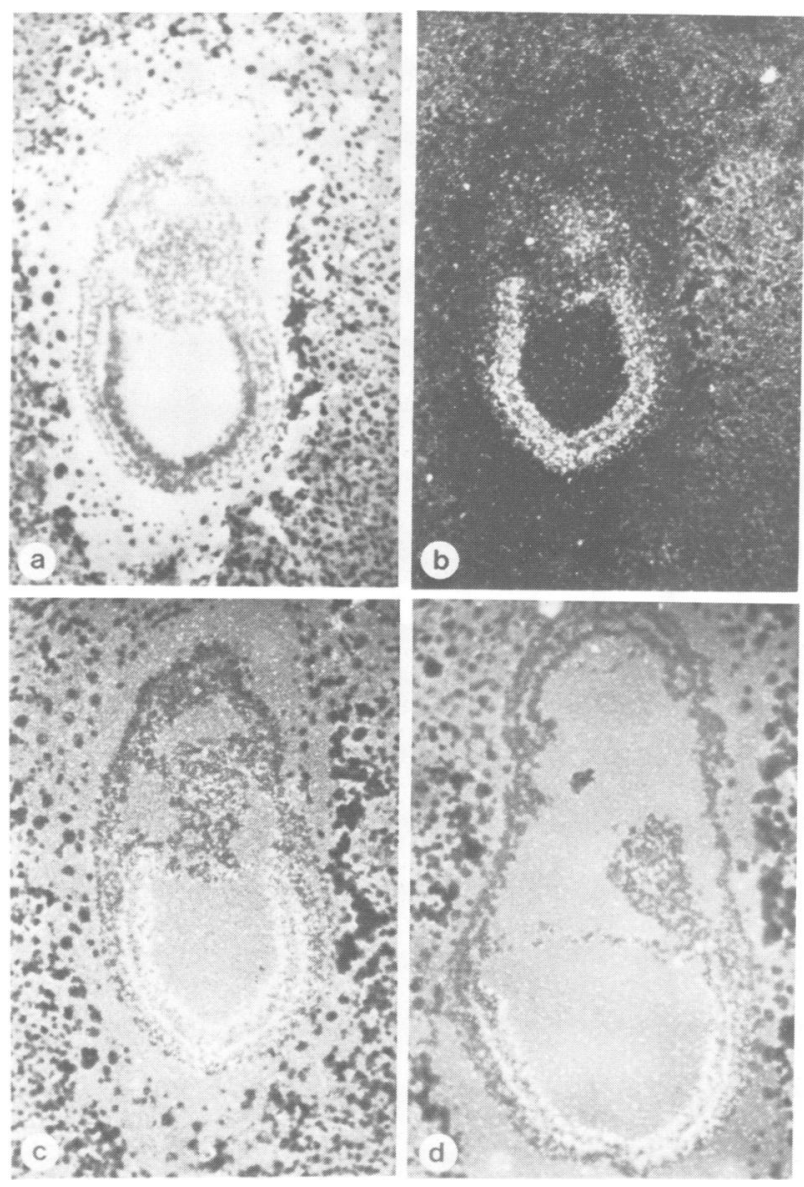

Fig. 4. In situ hybridization to 7 day embryos showing expression of Oct-4 in the embryonic ectoderm. A bright-field image (a) and two dark-field images $(\mathbf{b}, \mathbf{c})$ showing a mid-frontal view of serial sections of a day 7 embryo. In (d) a dark-field image of a sagittal section of a day 7.5 embryo is shown.

approximately day 8.5 in the neural tube and expression becomes restricted to germ cells thereafter. In accordance with the decrease of Oct-4 RNA, Oct-4 protein detected with EMSA decreases significantly between day 8.5 and 9.5 whereas the amount of Oct-1 protein detected increases (Figure 7). To normalize comparisons of different developmental stages in EMSA, poly $\mathrm{d}(\mathrm{I} \cdot \mathrm{C})$ was omitted and equal amounts of protein were used in each lane. Omission of poly $\mathrm{d}(\mathrm{I} \cdot \mathrm{C})$ resulted in additional nonspecific complexes which were found in every developmental stage and tissue tested, and could be destroyed by poly $\mathrm{d}(\mathrm{I} \cdot \mathrm{C})$ competition (not shown).

\section{Genetic mapping of the Oct-4 gene}

The map position of the Oct-4 gene was determined by recombinant inbred (RI) strain analysis (Taylor, 1978; Lyon and Searle, 1989). A RFLP between the C57BL/6J (B) and DBA/2J (D) strains of mice was identified using a $350 \mathrm{bp}$ fragment spanning the 5 ' region of the Oct-4 cDNA (fragment B; Figure 1A). The strain distribution pattern of the $B$ and $D$ alleles of the Oct-4 locus was then determined by hybridization of the $\mathrm{Oct}-4$ probe to Southern blots of genomic DNA of 26 strains in the $B \times D$ RI set. The strain distribution pattern is shown (Table $\mathrm{I}$ ) in comparison with those determined for other markers mapping to the MHC com- plex. No recombination was detected between $O c t-4$ and $T l a$ or $H 2-S$ in $26 \mathrm{RI}$ strains, therefore the map position of Oct-4 is likely to be within $0 \pm 4.2 \mathrm{cM}$ from the $H 2-S$ or $T l a(95 \%$ confidence; calculation according to Silver, 1985).

The Oct-4 locus separated from both the $\alpha$ A-crystallin gene (Crya-1) and Ms 15-3 in one strain of the B $\times$ D RI set; Oct-4 therefore maps between Crya-1 and Ms 15-3 (Table I; Vincek et al. , 1989). The estimated map distance of Ms 15-3 and $H-2$ is $1.1 \mathrm{cM}$ and thus $M s 15-3$ has been placed between $\mathrm{H}-2$ and Tla (Jeffreys et al., 1987; Lyon and Searle, 1989). This would mean that Oct-4 is within the MHC. However, as the markers D17Leh89 and D17Leh525 also show no recombination with Oct-4 in the $\mathrm{B} \times \mathrm{D}$ series and have been reported to map distally to Tla (Bucan et al., 1987), it cannot be excluded that Oct-4 and Ms15-3 map distally to the MHC complex (Silver, 1985).

The identical strain distribution patterns for the Oct-4 locus and for sequences in the $\mathrm{Tla}$ and $\mathrm{H2}-\mathrm{S}$ region indicate that Oct-4 maps at least near to the MHC complex. As a first attempt to see if $O c t-4$ is within the MHC, we examined whether Oct-4 sequences could be detected in any of the cosmids that span large parts of the H2-S, H2-D, H2-Qa and H2-Tla regions (Steinmetz et al., 1982, 1984; Fischer et al., 1985; Stephen et al., 1986; Müller et al., 1987). However, using the Oct-4 cDNA clone as a probe (fragment $A$ in Figure 1a), no positive signal was obtained.

\section{Discussion}

\section{Oct-4 acts as a transcription factor}

Oct-4 expression in HeLa cells was driven by the human CMV enhancer, which is very strong in these cells. Transactivation by Oct- 4 was studied with two sets of target vectors and the results were compared with those obtained with the Oct-2A transcription factor. The $6 \mathrm{~W}$ enhancer, a potent enhancer in F9 cells, was not activated by Oct-4 or Oct-2A in HeLa cells. However, a weak promoter consisting only of an octamer next to the TATA box was readily activated in HeLa cells. Several explanations might account for this discrepancy. First, the distances between the TATA boxes and the octamer are different. In the case of p6WtkCAT, the distance is $147 \mathrm{bp}$, whereas in $\mathrm{pD} \beta C A T$ both motifs are separated by only $20 \mathrm{bp}$. In p6WtkCAT, two GC boxes and one CAAT box are located between the octamer and the TATA box (Figure 9). However, the influence of the GC and CAAT boxes on transcriptional activation in p6WtkCAT remains to be determined. A distance effect between the octamer and TATA box has been described for B-cells (Wirth et al., 1987). When the octamer motif is within 40 bp upstream of the $\beta$-globin TATA, it is sufficient for directing lymphocyte-specific RNA synthesis. However, moving the octamer $\sim 220 \mathrm{bp}$ upstream of the TATA box did not induce transcription. Even with the ectopic expression of $O c t-4$ or $O c t-2 A$, the octamer motif might act as a proximal promoter element in HeLa cells. Similar results were also obtained by other groups (Müller-Immerglück et al., 1988, 1990; Tanaka and Herr, 1990). In their experiments co-transfected Oct-2A was only able to act on a nearby TATA and not from a position far upstream or downstream. In BJA-B cells, which contain abundant Oct-2A, even the downstream position was suitable for the stimulation of transcription (Gerster et al., 1987).

One explanation for the activity of $6 \mathrm{~W}$ in $\mathrm{F} 9$ cells is that 

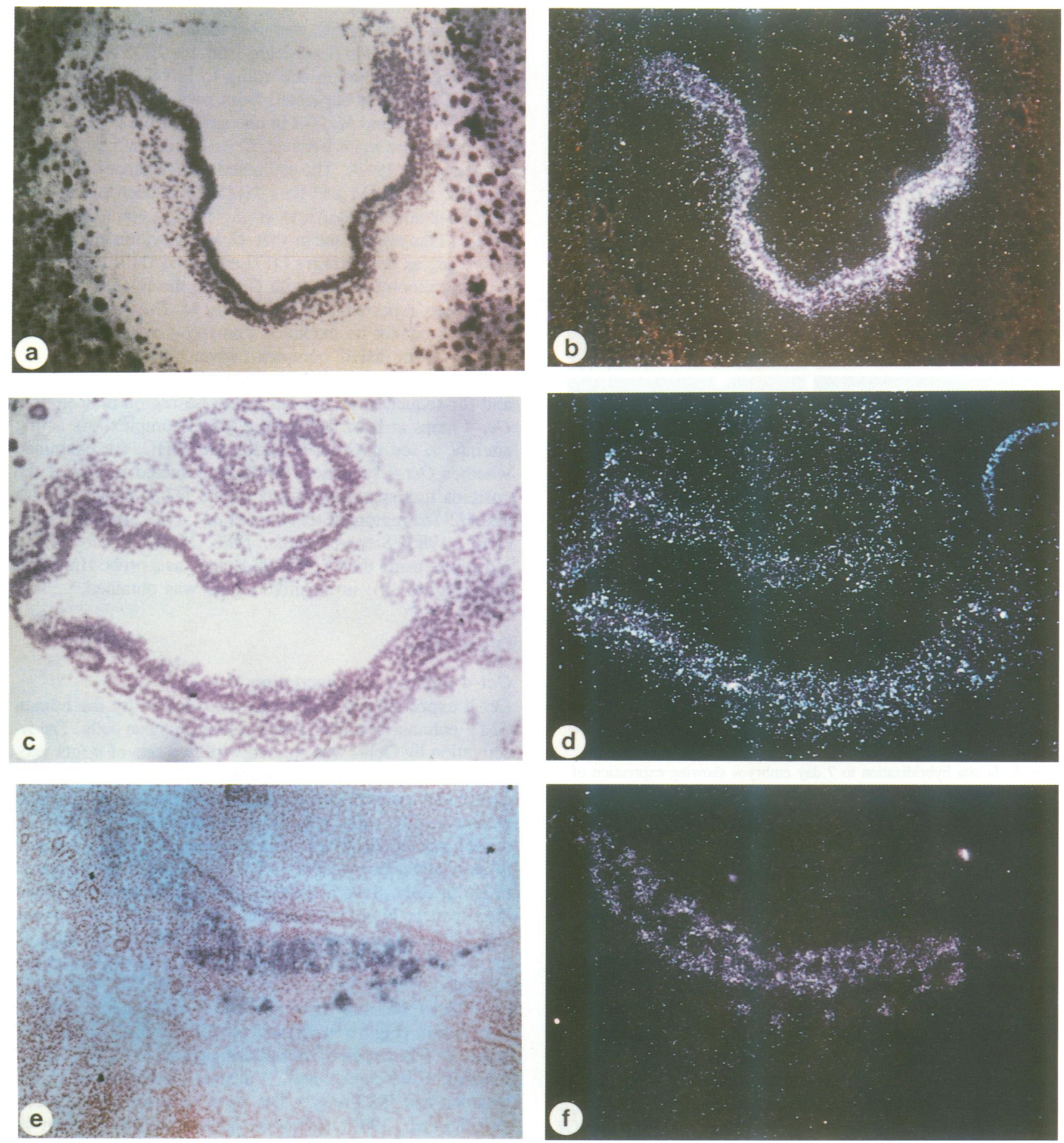

Fig. 5. Expression of Oct-4 in 8-day embryos and in primordial germ cells of an 11-day embryo. In situ hybridization to a sagittal section of a day $8(\mathbf{a}, \mathbf{b})$ and to a skewed sagittal section of a day 8.5 (c, d) embryo. (b) and (d) are dark-field images of (a) and (c), respectively. The headfold of each embryo is left, the allantois is right. (e) shows a bright-field image of a genital ridge (sagittal section of an 11-day embryo) stained for alkaline phosphatase activity. (f) is a dark-field image of a serial section of the genital ridge hybridized for Oct-4 expression.

proteins are present in these cells that are missing from HeLa. One putative site of interaction with such protein(s) is the hinge region between the first and second POU homeodomain helix of Oct-4 (Schöler et al., 1990). Alternatively, additional factors might be present in HeLa cells that do not allow Oct-4 to activate transcription from a distance. A third explanation is that binding of Oct-4 to (almost) all octamer sites is necessary for 6W to act as an enhancer. If not enough Oct-4 is present in the transactivation experiments, only a few sites would be occupied by Oct- 4 and the enhancer would be silent. Alternatively, the Oct-4/Oct-1 ratio could be important, because too much Oct-1 binding to $6 \mathrm{~W}$ might neutralize the effect of bound Oct-4. pD $\beta C A T$ contains only one octamer motif in front of the TATA box, therefore every bound Oct -4 activates transcription. In the $6 \mathrm{~W}$ enhancer experiments with F9 cells, 

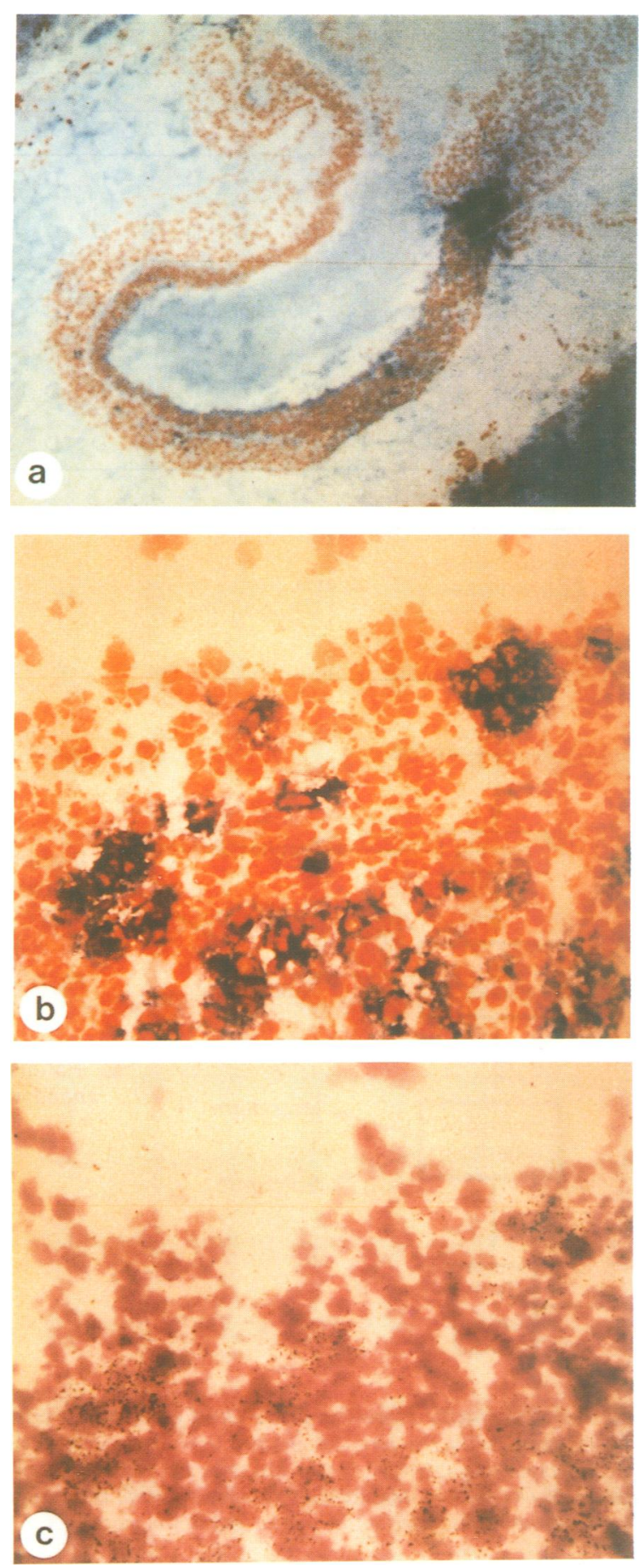

Fig. 6. Day 8.5 expression of $O c t-4$ in primordial germ cells. In (a) a sagittal section of a day 8.5 embryo is stained for alkaline phosphatase activity to show primordial germ cells at the base of the allantois. (b) and (c) are sections to compare alkaline phosphatase activity (b) and Oct-4 expression (c) at the cell level.

Oct-factors were not limiting. When different amounts of p6WtkCAT were transfected into F9 cells, adding carrier DNA to yield the same total amount of DNA, the 6W enhancer activity increased linearly (Schöler et al., 1989b). Finally, Oct -4 may act preferentially as a promoter transcription factor and Oct- 6 , which in addition to Oct-4 is also found in F9 cells, could be responsible for enhancer activation.

In a recent publication, Okamoto et al. (1990) described

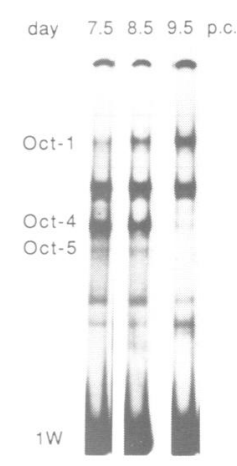

Fig. 7. Specific decrease of Oct-4 complexes during early mouse development. Radiolabelled $1 \mathrm{~W}$ was incubated with whole cell extracts of day 7.5 (lane 1) day 8.5 (lane 2) and day 9.5 (lane 3) embryos. The shifts correspond to extracts of less than one-quarter of an embryo each. Poly $\mathrm{d}(\mathrm{I} \cdot \mathrm{C})$ was omitted in this experiment to utilize additional DNA binding proteins as an internal standard. The positions of Oct-4 and Oct- 5 were determined by comparison with a F9 extract (not shown).

cDNA cloning of an octamer-binding protein (Oct-3) from a P19 library. We think that the Oct-3 protein is also encoded by the $O c t-4$ gene because the nucleotide sequences of the Oct-4 and Oct-3 cDNAs are identical except for two differences (Schöler et al., 1990). The identity of Oct-4 and Oct-3 is also indicated by Southern blot analysis with restriction-digested mouse DNA (data not shown).

In the functional analysis of the Oct-3 protein, Okamoto et al. (1990) used a target vector that had six tandem repeats of the octamer in front of the SV40 early promoter. Although this vector is active in P19 cells, trans-activation by Oct-3 in differentiated cells could not be demonstrated. This is similar to the results discussed above. To demonstrate that the $O c t-3$ cDNA encodes a transcription factor they used an indirect approach. When Oct-3 anti-sense RNA was expressed in P19 cells, the activity of the target decreased significantly, indicating that Oct-3 takes part in transcriptional activation.

\section{Oct-4 is a transcription factor specifically expressed in the germline}

The regulation of Oct-4 expression during early embryogenesis is a dynamic, multi-step process (Figure 8). Both male and female primordial germ cells express Oct- 4 as determined by EMSA (Schöler et al., 1989a) and in situ hybridization to mRNA. However, unfertilized oocytes contain Oct-4 protein whereas sperm does not. Upon fertilization, maternal Oct- 4 would be the only Oct- 4 source in the zygote until zygotic gene transcription is activated. The stage at which $O c t-4$ is first transcribed in the zygote is unclear. However, Oct-4 is actively transcribed in the preimplantation embryo and expression increases and continues only in the ICM during blastocyst development. Interestingly, the $6 \mathrm{~W}$ enhancer is active in ICM and not in the trophectoderm of transgenic blastocysts (Schöler et al., 1989b). The activity of the octamer in the ICM matches with its activity in the embryonal stem cell line D3, itself derived from the ICM of blastocysts. Moreover, the D3 cell line contains Oct-4 protein, as does the embryonal carcinoma cell line F9. In both cases the activity of the octamer motif correlates with the presence of Oct-4. Although a restriction of Oct-4 expression to the ICM is observed during blastocyst develop- 
Table I. Recombinant inbred strain $(\mathrm{B} \times \mathrm{D})$ segregation pattern of the Oct-4 gene

\begin{tabular}{|c|c|c|c|c|c|c|c|c|c|c|c|c|c|c|c|c|c|c|c|c|c|c|c|c|c|c|}
\hline \multirow[t]{2}{*}{ Locus } & \multicolumn{26}{|c|}{$B \times D$} \\
\hline & 1 & 2 & 5 & 6 & 8 & 9 & 11 & 12 & 13 & 14 & 15 & 16 & 18 & 19 & 20 & 21 & 22 & 23 & 24 & 25 & 27 & 28 & 29 & 30 & 31 & 32 \\
\hline Crya-1 & D & B & D & D & B & $\mathrm{D}$ & D & D & B & B & B & D & D & B & B & D & D & B & D & D & $\begin{array}{l}\mathbf{B} \\
\mathbf{X}\end{array}$ & D & B & D & D & D \\
\hline$H 2-S$ & D & B & D & D & B & $\mathrm{D}$ & D & $\mathrm{D}$ & B & B & B & D & D & B & B & D & D & B & D & D & D & D & B & D & D & D \\
\hline $\begin{array}{l}\text { Tla } \\
\text { D17Leh89 } \\
\text { D17Leh525 }\end{array}$ & D & B & D & D & B & D & $\mathrm{D}$ & D & B & B & B & D & D & B & B & D & D & B & D & D & D & D & B & D & D & D \\
\hline Oct-4 & D & B & D & D & B & D & D & $\begin{array}{l}\mathrm{D} \\
\mathbf{x}\end{array}$ & B & B & B & D & D & B & B & D & D & B & D & $\mathrm{D}$ & D & D & B & D & D & D \\
\hline Ms15-3 & D & B & D & D & B & D & $\mathrm{D}$ & $\mathbf{B}$ & B & B & B & D & D & B & B & D & D & B & D & D & $\mathrm{D}$ & D & B & D & D & D \\
\hline
\end{tabular}

ment, the question remains why the octamer motif is not active in trophoblast cells. The same reasons as outlined which lead to the lack of trans-activation of the $6 \mathrm{~W}$ enhancer in HeLa cells might also account for the lack of activity in the trophoblast (see above). In addition, although Oct-4 transcripts are readily detectable in the trophoblast, it remains unclear whether they lead to an active translation product.

It also remains unclear why Oct-4 is expressed in embryonic ectoderm and neural ectoderm. Prior to day 7 , cells of the embryonic ectoderm have some degree of pluripotency and can give rise to many different cell types in teratocarcinomas (Evans and Kaufman, 1983). Studies addressing the potency of embryonic ectoderm (Beddington, 1981, 1982; Snow, 1981; Snow and Monk, 1983) indicate that distal ectoderm just posterior to the primitive streak from 7 day embryos can contribute to a variety of structures including somites, mesoderm, gut endoderm and notochord. Anterior ectoderm is more restricted in developmental potency and contributes primarily to head surface ectoderm and head neural ectoderm. The regional specification of the 7 day embryo is described in detail by Snow (1981) and Tam (1989) and appears to precede cell-type restriction, as there is little cell mixing along the anterior-posterior axis. The potency of ectodermal cells becomes more and more restricted beginning at approximately day 7 . Although the three primary germ cell layers are all derived from the embryonic ectoderm, only the neural ectoderm still expresses Oct-4 at day 8. Thus, as cells of the ectoderm ingress through the primitive streak and form mesoderm, Oct-4 expression is shut off. Similarly, as the developmental potency of ectoderm cells in the neural plate becomes more restricted, Oct-4 expression is turned off. Only the primordial germ cells, also derived from ectoderm (Snow, 1981; Tam, 1989), continue to express $\mathrm{Oct}-4$; their developmental potency is unlimited, once differentiated and fertilized. In summary, Oct- 4 may be required to maintain potency in the cells of the early embryo.

\section{Oct-4 maps in or near the major histocompatibility complex}

The chromosomal location of the $\mathrm{Oct}-4$ gene was determined by recombinant inbred strain analysis (Taylor, 1978). The same strain distribution pattern for Oct-4, Tla and $\mathrm{H2}-\mathrm{S}$ was found, indicating that $O c t-4$ maps on chromosome 17 in or near the MHC complex (Lyon and Searle, 1989). The MHC complex is located at the distal region of the $t$-complex, for which several dominant and recessive mutations are known (for a review see Frischauf, 1985).

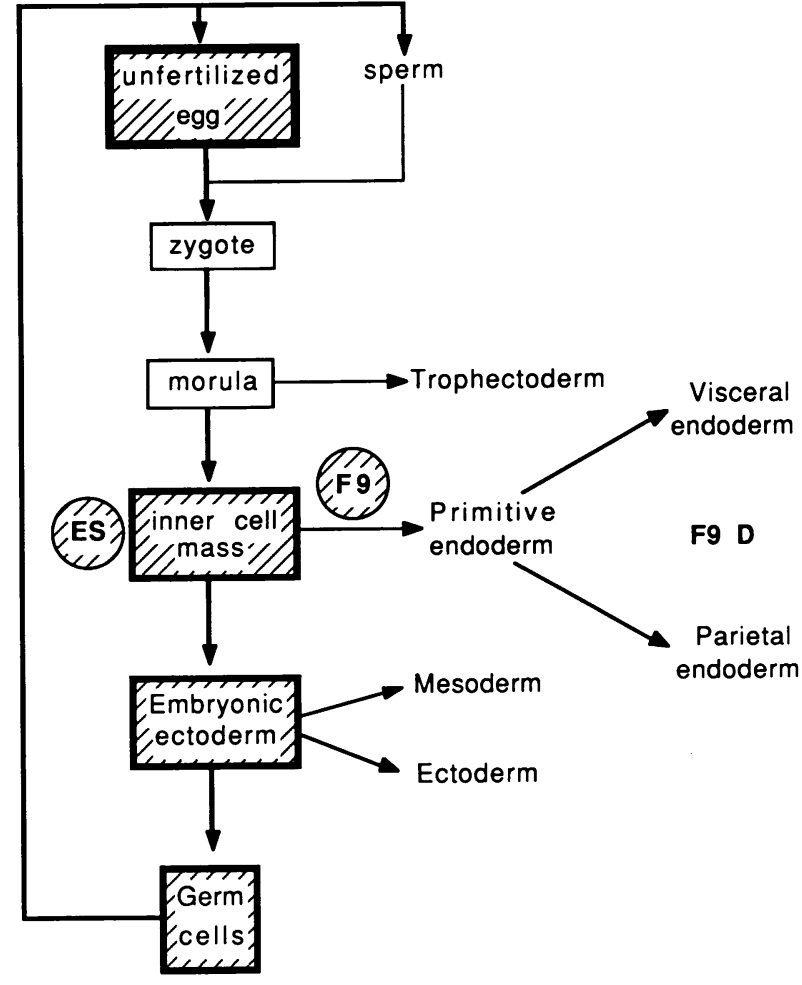

Fig. 8. Germline specific expression of the $\mathrm{Oct}-4$ gene. Boxes: cells and tissues representing the germline; hatched boxes and circles: cells and tissues expressing $O c t-4$; in tissues and cells that are not framed, expression of $\mathrm{Oct}-4$ is not detectable or strongly reduced; expression of $O c t-4$ was not investigated in the zygote and in the morula.

Several of the $t$-haplotype lethal alleles mapping to the MHC complex have profound effects on early mouse development. One complementation group is characterized by the failure of blastocyst formation on day 3 of development $\left(t^{12}\right.$ and $\left.t^{w 32}\right)$, a second shows defects in the formation of embryonic ectoderm $\left(t^{0}\right.$ and $\left.t^{\sigma}\right)$ and a third leads to death of embryonic ectoderm $\left(t^{w 5}\right)$ (Magnuson, 1983 and ref. therein). $t^{D}$ and $t^{6}$ belong to a cluster of $t$-lethal alleles mapping close to tufted $(t f)$ and therefore are too far away to be due to a mutation of the Oct-4 locus. However, the other two groups belong to a cluster of $t$-lethal alleles associated with the MHC locus (Artzt, 1984; Shin et al., 1984).

Because Oct-4 is expressed during preimplantation development, $t$-lethal mutant phenotypes, which fail to form 

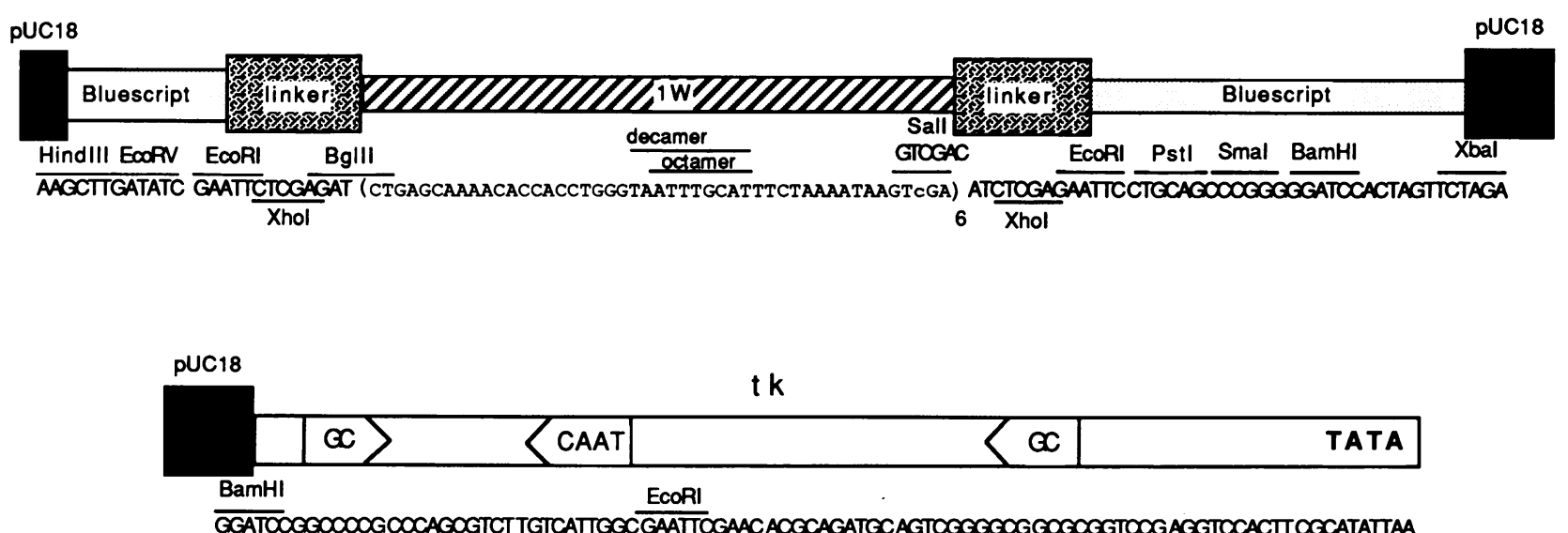

Fig. 9. Sequence of the 6Wtk promoter region. Construction of p6WtkCAT as described by Schöler et al. (1989b). The octamer motif, the TATA, $\mathrm{GC}$ and CAAT boxes are indicated above the sequence.

blastocysts, may be the result of a mutation or a deletion in the $0 c t-4$ gene. $t^{12}$ and $t^{w 32}$ result in preimplantation lethality when homozygous. $t^{12}$ homozygous embryos arrest in development at the late morula stage ( $\sim 32$ cells ) (Smith, 1956) whereas those homozygous for $t^{w 32}$ arrest in development at the early morula stage ( $\sim 16$ cells) (Hillman et al., 1970). $t^{12} / t^{w 32}$ heterozygotes also die at the early morula stage (Hillman, 1975).

The death of the embryonic ectoderm of $t^{w 5}$ homozygotes at day 7-8 correlates with the high levels of $O c t-4$ expression at this time. Some $t^{w 5}$ embryos develop to 10 days although they become completely extraembryonic and consist of only yolk sac, chorion and allantois (Bennett and Dunn, 1958).

$t^{\text {lubl }}$ (Winking and Guenet, 1978) is another allele belonging to the cluster of $t$-lethals associated with the MHC (Artzt, 1984). However, extracts from an embryonal stem cell line homozygous for $t^{\text {lubl }}$ gave a strong Oct-4 complex in EMSA, indicating that synthesis of Oct- 4 occurs and binding is not affected (data not shown).

Oct-4 is present in primordial germ cells, unfertilized oocytes and in the mouse blastocyst. Therefore this transcription factor could be regulating very early developmental processes, acting prior to other putative control genes, such as Hox or Pax genes. It will be interesting to determine whether Oct-4 regulates members of other gene families (Dressler and Gruss, 1988). The dramatic down-regulation of Oct-4 expression after day 8 might be necessary for the differentiation of the embryonic ectoderm into different tissues. Although we have demonstrated that Oct- 4 can act as a transcription factor, it might also repress transcription when the octamer motif is in a different context (Lenardo et al., 1989). A more detailed mapping of the $O c t-4$ gene in relation to any of the $t$-mutants might allow a functional analysis. Taken together, we think that $O c t-4$ is a good candidate for a gene involved in control events of early mouse development.

\section{Materials and methods}

\section{Cell lines and transfection}

HeLa cells were grown and transfected as described elsewhere (Schöler and Gruss, 1984; Schöler et al., 1989b). HeLa cells were transfected with $15 \mu \mathrm{g}$ reporter plasmid, $5 \mu \mathrm{g}$ expression vectors and $5 \mu \mathrm{g} \beta$-actin-LacZ. After harvesting, one-tenth of the cells were used for the microextraction procedure.

\section{Recombinant plasmids and oligonucleotides}

ptkCAT, p6WtkCAT, p6FdtkCAT and the Oct-4 cDNA clone have been described previously (Schöler et al., 1989b and 1990). The sequence of the $6 \mathrm{Wtk}$ promoter is shown in Figure 9. CMV-Oct2A(+) has been described by Müller-Immerglück et al. (1988). The Oct-2A cDNA in CMV-Oct2A(+) was replaced by Oct-4 cDNA (Figure 1a; fragment A) in either sense or anti-sense orientation by standard recombinant procedures. Both SmaI restriction sites of CMV-Oct2A(+) were used for the replacement (E.Schreiber, personal communication). $\mathrm{pD} \beta C A \mathrm{~T}$ and $\mathrm{pd} \beta C A \mathrm{~T}$ were constructed by replacing the $\mathrm{XbaI}-\mathrm{Xhol}$ fragment of ptkCAT (including the tk promoter) with the synthetic oligonucleotides indicated in Figure 1d. $\beta$-actin-lac $Z$ is a plasmid containing the lac $Z$ gene driven by the human $\beta$-actin promoter (A.Püschel, unpublished data). The $1 \mathrm{~W}$ oligonucleotide has been described previously (Schöler et al., 1989a).

\section{CAT and $\beta$-galactosidase assays}

CAT assays were performed as described elsewhere (Schöler and Gruss, 1984) with the following modifications: $150 \mu \mathrm{l}$ of a total of $180 \mu \mathrm{l}$ were incubated for $3 \mathrm{~h}$ and $4 \mathrm{mM}$ acetyl-CoA was added after 60 and $120 \mathrm{~min}$. Autoradiography was performed for $72 \mathrm{~h}$. $\beta$-galactosidase assays were performed as described in Sambrook et al. (1989).

\section{Isolation of blastocysts and day 7.5-9.5 p.c. embryos}

Day 3.5 (blastocysts), 7.5, 8.5 and 9.5 embryos were isolated as described by Hogan et al. (1986). Decidual tissue (day 7.5) and visceral yolk sac (day 8.5 and 9.5 ) were discarded and the embryos frozen immediately in liquid nitrogen.

\section{Microextraction procedure for the preparation of whole cell} extracts and the electrophoretic mobility shift assay (EMSA) The microextraction procedure and the EMSA were performed as described previously (Schöler et al., 1989a) except for using $100 \mathrm{mM} \mathrm{NaCl}$ in the extraction buffer.

\section{DNA isolation and analysis}

Total cellular DNA from C57BL/6J and DBA/2J mice was isolated by standard techniques. B $\times$ D RI strain DNA was purchased from the Jackson Laboratory (Bar Harbor, Maine). Genomic DNA was digested, separated by electrophoresis and blotted onto GeneScreen Plus membrane by alkaline transfer. The filters were baked at $80^{\circ} \mathrm{C}$ for $30 \mathrm{~min}$ and hybridized overnight at $42^{\circ} \mathrm{C}$ in $50 \%$ formamide, $1 \% \mathrm{SDS}, 1 \mathrm{M} \mathrm{NaCl}$ with the $O c t-4$ probe (Figure 1a; fragment B). The filters were washed twice at room temperature for $30 \mathrm{~min}$ in $2 \times \mathrm{SSC}$, twice at $65^{\circ} \mathrm{C}$ for $30 \mathrm{~min}$ in $2 \times \mathrm{SSC}, 1 \%$ SDS and finally twice in $0.1 \times \mathrm{SSC}$ at $65^{\circ} \mathrm{C}$ for $30 \mathrm{~min}$.

\section{In situ hybridization (Figures 4, 5, 6)}

The techniques employed for in situ hybridization were essentially those of Hogan et al. (1986) with modifications by Dony and Gruss (1987). Day $6,7,8$ and 9 embryos were dissected out of the uterus but left in the decidua for sectioning. Day 11 embryos were dissected free of extra-embryonic tissues prior to sectioning. $8 \mu \mathrm{m}$ sections were cut at $-20^{\circ} \mathrm{C}$, dried for $10-15 \mathrm{~min}$ at $55^{\circ} \mathrm{C}$ and fixed in $4 \%$ paraformaldehyde. Sections were pretreated in $2 \times \mathrm{SSC}$ at $70^{\circ} \mathrm{C}$ for $30 \mathrm{~min}$ and digested with $0.1 \mathrm{mg} / \mathrm{ml}$ pronase for $10 \mathrm{~min}$ at room temperature. After rinsing in PBS, sections were refixed in paraformaldehyde and dehydrated in graded ethanol. 
A 462 bp Oct-4 cDNA fragment (fragment C in Figure 1a) was cloned into Bluescript (Stratagene) and linearized with an appropriate restriction endonuclease. The highest homology of this probe to a known DNA sequence is $<70 \%$ (tst-I; N.Suzuki and H.R.Schöler, unpublished results). RNA probes were transcribed using $\mathrm{T} 3$ and $\mathrm{T} 7$ polymerases according to the manufacturer's instructions (Promega). Labelled RNAs were precipitated with 10\% TCA and collected on nitrocellulose filters. Probes were eluted from the filters in $50 \mathrm{mM}$ EDTA, $0.1 \% \mathrm{SDS}$ at $65^{\circ} \mathrm{C}$ for $30 \mathrm{~min}$ and subjected to limited alkaline hydrolysis to achieve an optimum probe length of $100-200$ nucleotides. Probes were diluted to $5 \times 10^{4}$ c.p.m. $/ \mu \mathrm{l}$ in hybridization buffer containing $50 \%$ formamide, $10 \%$ dextran sulphate, 0.3 $\mathrm{M} \mathrm{NaCl}, 10 \mathrm{mM}$ Tris, $10 \mathrm{mM} \mathrm{NaPO} \mathrm{pH}_{4} 6.8,5 \mathrm{mM}$ EDTA, $10 \mathrm{mM}$ DTT, $1 \times$ Denhardt's, and $10 \mu \mathrm{M}\left[{ }^{35} \mathrm{~S}\right] \mathrm{ATP}$. Approximately $6-10 \mu \mathrm{l}$ of hybridization mix was used per section, depending on the size of the coverslip. Hybridization was performed overnight at $42^{\circ} \mathrm{C}$ in a humid chamber. Slides were washed at $50^{\circ} \mathrm{C}$ in $2 \times \mathrm{SSC}, 50 \%$ formamide at $37^{\circ} \mathrm{C}$ until coverslips floated free. Slides were digested with $20 \mu \mathrm{g} / \mathrm{ml}$ of pancreatic RNase (Ingham et al., 1985) and washed overnight at $37^{\circ} \mathrm{C}$ in $50 \%$ formamide, $2 \times$ SSC. Slides were dipped in Kodak NTB2 emulsion and exposed for 7 days. Slides were developed and stained with thionin.

Alkaline phosphatase activity was detected ujsing the method of Stinnakre et al. (1981). The sections were fixed as for in situ hybridization and dehydrated. Sections were incubated for $10 \mathrm{~min}$ in $75 \mathrm{mM}$ Tris $\mathrm{pH} 8.6$, $0.8 \% \mathrm{NaCl}, 2 \%$ dimethylformamide, $0.05 \%$ sodium napthol ASMX phosphate and $0.1 \%$ fast red TR. Sections were rinsed in water briefly and counterstained for $1 \mathrm{~min}$ in neutral red.

\section{In situ hybridization (Figure 3)}

The techniques employed for in situ hybridization of blastocysts were those of Hogan et al. (1989) and Graham et al. (1989). Blastocysts were recovered from the oviduct and uterus (Hogan et al., 1989) and transferred into oviducts. Subsequently, the oviduct was dissected, fixed in $4 \%$ paraformaldehyde for $16 \mathrm{~h}$ at $4^{\circ} \mathrm{C}$ and embedded in paraffin wax. $6 \mu \mathrm{m}$ sections were cut and dried for $60 \mathrm{~min}$ at $37^{\circ} \mathrm{C}$. The sections were dewaxed in xylene, refixed in $4 \%$ paraformaldehyde, digested with $0.02 \mathrm{mg} / \mathrm{ml}$ proteinase $\mathrm{K}$ and treated with acetic anhydride. After dehydration the sections were hybridized with the probe (see above) for $16 \mathrm{~h}$ at $50^{\circ} \mathrm{C}$ in a hybridization buffer containing $50 \%$ formamide, $10 \%$ dextran sulphate, $100 \mathrm{mM}$ DTT, $0.3 \mathrm{M} \mathrm{NaCl}, 110 \mathrm{mM}$ Tris, $5 \mathrm{mM}$ EDTA, $10 \mathrm{mM}$ sodium phosphate, $2 \%$ BSA, $2 \%$ polyvinylpyrrolidone, $2 \%$ Ficoll type 400 . Slides were washed at $37^{\circ} \mathrm{C}$ in $2 \% \mathrm{SSC}, 50 \%$ formamide, $1 \mathrm{mM}$ DTT for $4 \mathrm{~h}$ and subsequently treated with $20 \mu \mathrm{g} / \mathrm{ml} \mathrm{RNase} \mathrm{A}$ at $37^{\circ} \mathrm{C}$ for $15 \mathrm{~min}$. Washing was continued for $16 \mathrm{~h}$ at $37^{\circ} \mathrm{C}$ in $2 \% \mathrm{SSC}, 50 \%$ formamide, $1 \mathrm{mM}$ DTT, then slides were dehydrated and air dried. Slides were dipped in Kodak NTB2 emulsion, exposed for 10 days, developed and stained with Giemsa.

\section{Acknowledgements}

We thank C.Peiker and M.Olowson for their excellent technical assistance, R.Altschäffel for the photographic work and H.P.Geithe for the oligonucleotides. Once again we are grateful to W.Schaffner (and E.Schreiber) for the support with plasmids (pCMV-Oct-2A and two reporter plasmids). We thank M.Steinmetz for the MHC cosmids and R.Kemler and A.Mansouri for providing us with $t^{l u b l}$ cells. Last but not least we also thank our colleagues A.Püschel and M.Gross for valuable comments on the manuscript, N.Suzuki and A.Mansouri for stimulating discussions, T.Ciesiolka for $\mathrm{pD} \beta C A T$ and $\mathrm{pd} \beta C A T$ and again A.Püschel for $\mathrm{p} \beta$ actin-lacZ. G.D. was supported by Alexander von Humboldt Fellowships. H.R. was supported by a Boehringer Ingelheim Fond Fellowship. This project was supported by the Max-Planck Society and by the Bundesministerium für Forschung und Technologie (BMFT).

\section{References}

Artzt,K. (1984) Cell, 39, 565-572.

Beddington,R.S.P. (1981) J. Embryol. Exp. Morphol., 64, 87-104. Beddington,R.S.P. (1982) J. Embryol. Exp. Morphol., 69, 265-285. Bennett,D. and Dunn,L.C. (1958) J. Morphol., 103, 135-157.

Bucan,M., Herrmann,B.G., Frischauf,A.-M., Bautch,V.L., Bode,V.,

Silver,L.M., Martin, G.M. and Lehrach,H. Genes Dev., 1, 376-385. Chiquoine,A.D. (1954) Anat. Rec., 118, 135-146.

Church,G.M., Ephrussi,A., Gilbert,W. and Tonegawa,S. (1985) Nature,

313, 798-801.

Clark,J.M. and Eddy,E.M. (1975) Dev. Biol., 47, 136-155.

Dony,C. and Gruss,P. (1987) EMBO J., 6, 2965-2975.

Dressler,G.R. and Gruss,P. (1988) Trends Genet., 4, 214-219.
Dreyfus,M., Doyen,N. and Rougeon,F. (1987) EMBO J., 6, 1685-1690. Ephrussi,A., Church,G.M., Tonegawa,S. and Gilbert,W. (1985) Science, 227, 134-140.

Evans,M.J. and Kaufman, M.H. (1983) Cancer Surv., 2, 185-207.

Fischer,D.A., Hunt III,S.W. and Hood,L. (1985) J. Exp. Med., 162, $528-545$.

Fogh,J. (1978) Nat. Cancer Inst. Monogr., 49, 5-19.

Frischauf,A.-M. (1985) Trends Genet., 1, 100-103.

Gerster,T., Matthias,P., Thali,M., Jiricny,J. and Schaffner,W. (1987) $E M B O$ J., 6, 1323-1330.

Graham,A., Papalopulu,N. and Krumlauf,R. (1989) Cell, 57, 367-378.

Hatzopoulos,A.K., Schlokat,U. and Gruss,P. (1988) In Hames,B.D. and Glover,D.M. (eds), Transcription and Splicing, Frontiers in Molecular Biology. IRL Press, Oxford, pp. 43-96.

Hillman, N. (1975) In Balls,M. and Wild,A.E. (eds), The Early Development of Mammals. Cambridge University Press, pp. 189-206.

Hillman,N., Hillman,R. and Wileman,G. (1970) Am. J. Anat., 128, $311-340$.

Hogan,B., Constantini,F. and Lacy,E. (1986) Manipulating the Mouse Embryo: a Laboratory Manual. Cold Spring Harbor Laboratory Press, Cold Spring Harbor, NY

Holland,P.W.H. and Hogan,B.L.M. (1988) Genes Dev., 2, 773-782. Ingham,P.W. (1988) Nature, 335, 25-34.

Ingham,P.W., Howard,K. and Ish-Horowicz,D. (1985) Nature, 318 , $439-445$.

Jeffreys,A.J., Wilson,V., Kelly,R., Taylor,B.A. and Bulfield,G. (1987) Nucleic Acids Res., 15, 2823-2836.

Kessel,M. and Gruss,P. (1990), Science, in press.

LeBowitz,J.H., Kobayashi,T., Staudt,L., Baltimore,D. and Sharp,P.A. (1988) Genes Dev., 2, 1227-1237.

Lenardo,M.J., Staudt,L., Robbins,P., Kuang,A., Mulligan,R.C. and Baltimore,D. (1989) Science, 243, 544-546.

Lyon,M. and Searle,A.G. (1989) Genetic Variants and Strains of the Laboratory mouse. 2nd edition. Oxford University Press, Fischer, Stuttgart.

Lyons,K.M., Pelton,R.W. and Hogan,B.L.M. (1989) Genes Dev., 3, $1657-1668$.

Magnuson,T. (1983) In Johnson,M.H. (ed.), Development in Mammals. Volume 5. Elsevier, Amsterdam, pp. 209-249.

Müller,U., Stephan,D., Philippsen,P. and Steinmetz,M. (1987) EMBO J., 6, 369-373.

Müller-Immerglück,M.M., Ruppert,S., Schaffner,W. and Matthias,P. (1988) Nature, 336, 544-551.

Müller-Immerglück,M.M., Schaffner,W. and Matthias,P. (1990) EMBO $J .$, 9, $1625-1634$.

Okamoto,K., Okazawa,H., Okuda,A., Sakai,M., Muramatsu,M. and Hamada,H. (1990) Cell, 60, 461-472.

Pedersen,T. and Peters,H. (1968) J. Repro. Fert., 17, 555-557.

Sambrook,J., Fritsch,E.F. and Maniatis,T. (1989) Molecular Cloning: a Laboratory Manual. (2nd edition). Cold Spring Harbor Laboratory Press, Cold Spring Harbor, NY.

Scheidereit,C., Heguy,A. and Roeder,R.G. (1987) Cell, 51, 783-793.

Schöler,H.R. and Gruss,P. (1984) Cell, 36, 403-411.

Schöler,H.R., Hatzopoulos,A.K., Balling,R., Suzuki,N. and Gruss,P. (1989a) EMBO J., 8, 2543-2550.

Schöler,H.R., Balling,R., Hatzopoulos,A.K., Suzuki,N. and Gruss,P. (1989b) EMBO J., 8, 2551-2557.

Schöler,H.R., Ruppert,S., Suzuki,N., Chowdhury,K. and Gruss,P. (1990), Nature, 344, 435-439.

Schreiber,E., Matthias,P., Müller-Immerglück,M.M. and Schaffner,W. (1988) EMBO J., 7, 4221-4229.

Severne,Y., Wieland,S., Schaffner,W. and Rusconi,S. (1988) EMBO J., 7, 2503-2508.

Shin,H.-S., Bennett,D. and Artzt,K. (1984) Cell, 39, 573-578.

Silver,J. (1985) J. Hered., 76, 436-440.

Smith,L.J. (1956) J. Exp. Zool., 132, 51-83.

Snow,M.H.L. (1981) J. Embryol. Exp. Morphol., (suppl.), 65, 269-287.

Snow,M.H.L. and Monk,M. (1983) In McLaren,A. and Wylie,C.C. (eds), Current Problems in Germ Cell Differentiation. Cambridge University Press, England, pp. 115-136.

Steinmetz,M., Winoto,A., Minard,K. and Hood,L. (1982) Cell, 28, 489-498.

Steinmetz,M., Malissen,M., Hood,L., Ö̈n,A., Maki,R.A., Dastoornikoo,G.R., Stephan,D., Gibb,E. and Romaniuk,R. (1984) EMBO J., 3, 2995-3003.

Stephan,D., Sun,H., Lindahl,K.F., Meyer,E., Hämmerling,G., Hood,L. and Steinmetz,M. (1986) J. Exp. Med., 163, 1227-1244. 
Stinnakre,M.G., Evans,M.J., Wilson,K.R. and Stern,P. (1981) J. Embryol. Exp. Morphol., 61, 117-131.

Tam,P.P.L. (1989) Development, 107, 55-67.

Tanaka,M., Grossniklaus,U., Herr,W. and Hernandez,N. (1988) Genes Dev., 2, 1764-1778.

Tanaka,M. and Herr,W. (1990) Cell, 60, 375-386.

Taylor,B.A. (1978) In Morse,H.C. III (ed.), Origins of Inbred Mice. Academic Press, NY, pp. 432-438.

Thali,M., Müller-Immerglück,M.M., Delorenzo,M., Matthias,P. and Bienz,M. (1988) Nature, 336, 598-601.

Vincek,V., Kawacuchi,H., Mizuno,K., Zaleska-Rutczynska,Z., Kasahara,M., Forejt,J., Figueroa,F. and Klein,J. (1989) Genomics, 5, $773-786$.

Winking,H. and Guenet,J.-H. (1978) Mouse News Letter, 59, 33.

Wirth,T., Staudt,L. and Baltimore,D. (1987) Nature, 329, 174- 178.

Received on March 13, 1990; revised on April 19, 1990

\section{Note added in proof}

The symbol $O c t-4$ has been accepted by the Committee on 'Standardized Genetic Nomenclature for Mice' and will be published together with the mapping in the July issue of Mouse News Letter. 